\title{
Recently discovered shipwrecks in Sri Lankan waters
}

\author{
Rasika Muthucumarana* \\ Maritime Archaeology Unit, Central Cultural Fund, Fort, Galle, Sri Lanka
}

During the last fifty years, many wrecks of Dutch and European steam powered ships, circa 17 th century $C E$ have been discovered around Sri Lanka. Stone anchors used by Chinese and Arab traders of 13th-14th century $C E$ are suggestive of wrecks of different origins. The era beyond that is shrouded in mystery. Recent investigations by the Maritime Archaeology Unit of Sri Lanka have shed light on some of these ancient ghosts. A wooden wreck located in 2008 in southern Sri Lanka was dated to the 2 nd century BCE. Now known as the Godawaya wreck and it is still under excavation as of this now. Another, known as SS Indus, wrecked in 1885 containing treasures of precious antiquities for the British Museum, was found on the north coast.

Keywords: Bharhut, cargo, Godawaya, Indian Ocean trade, SS Indus, wooden wreck.

\section{Introduction}

'A journey ends with terrifying suddenness, sending a majestic seagoing vessel to the ocean floor, ending the life of sailors and passengers. The wreck is now a home to sea creatures, corals and sponges. Years later, detectives in forms of maritime archaeologists locate the wreck and start to piece together tiny bits of information, like a forensic scientist who attempt to work out the cause of death, to unearth the story of that forgotten hulk sitting along in its watery grave. This story is a small part of a larger one which consists on many - the cement between the bricks that make the whole tapestry of our history. But, what if there is a wreck without a story, or a wreck without any clue or evidence to trace its name, date of build or when it sank? For the archaeologists, this is the beginning of a whole new episode, imaginary and real, the latter requiring interpretation of small clues - intense detective work, ${ }^{1}$

Shipwrecks invariably attract a great deal of attention due to the drama, tragedy and mystery associated with their demise, creating much publicity. This fired the public imagination with its links to recent and ancient history and generated a great deal of public interest in maritime archaeology. In the early 1960s, sports divers Arthur C.

*e-mail: muthurasika@gmail.com
Clarke, Mike Wilson and Rodney Jonklaas' chance discovery of silver coins on a wreck near the Great Basses lighthouse in southern Sri Lanka lit the light of maritime archaeology. The wreck is known as the 'Silver Wreck' because it was carrying sacks of Moghul silver coins dated 1702 CE minted in Surat, India ${ }^{2}$. Later, in 1993, the discovery of a VOC ship named the Avondster established the foundation of maritime archaeology in Sri Lanka. A well-preserved half buried wooden hull of a ship in the shallow waters of the Galle Harbour made a perfect site to train young archaeologist and conservators. With funds from the Netherlands, the Central Cultural Fund (CCF), and the Department of Archaeology carried out the excavation project on this shipwreck sunk in 1659 CE. This three-year project (2001-2004) resulted in the creation of the Maritime Archaeology Unit (MAU) in Galle to safeguard the underwater cultural heritage of the country ${ }^{3}$.

Following early research and explorations connected with the Galle Harbour Project of 1992, the CCF and the Department of Archaeology took an initiative to train tertiary graduates in maritime archaeology and conservation. The Maritime Archaeology Unit (MAU) was founded in 2001 under the aegis of the Mutual Heritage Centre (the Netherland-Sri Lanka Cultural Cooperation Programme). This research unit, staff and annual fieldwork are now managed and funded by the CCF. The unit consists of an archaeological diving unit, conservation laboratory and a small research library, situated on one of the jetties of the old Galle harbour ${ }^{4}$. The Dutch warehouse in the Galle Fort was conserved by the CCF and transformed into Sri Lanka's first maritime archaeological museum in 2010 and proved to be highly popular with visitors to the Fort. Most of the artefacts discovered by the MAU are stored and exhibited in this museum following conservation treatment. The main library and the administrative division of the MAU are stored and exhibited inside the museum.

Since 2001, the MAU conducted its field work and explorations in and around the Galle harbour and along the south coast which is affected by annual monsoon switch lasting from April through October, the non-diving season. From mid-October to April, the sea conditions are favourable for field work. Following the Avondster project, the MAU started working independently and expanded its field work to deeper waters. From 2005 to 
2010 the MAU spent more time along the south coast discovering more shipwrecks and other underwater cultural sites. The Godawaya shipwreck was found during one of these explorations, with assistance from two local divers.

\section{Godawaya the ancient shipwreck site}

In October 2008, the MAU commenced exploration with funds from UNESCO Bangkok to find new shipwrecks along the south coast. The plan was to study the wreck sites from Great Basses reef to Matara. After recording shipwreck sites around Great Basses, the exploration team came to Godawaya (Figure 1). In 2003, two local divers (R. Sunil and G. B. Peminda) from the Godawaya fishing village found a place with some wooden remains and potshards from the sea. Following this lead, the MAU team dived to a depth of $32 \mathrm{~m}$ between the Godawaya and Hambanthota area on the 18 October 2008 and found a wooden wreck on the sandy seabed covered with corals and sea plants. The wooden mound/hull was surrounded by hundreds of potsherds plus complete pottery, glass ingots, stone objects and iron materials on the site ${ }^{5}$.

Godawaya is a small fishing village located near the mouth of Walave River, the second largest river in the country. An ancient temple bearing the same name is situated on the left bank of this river. Two inscriptions found at the Godawaya temple were first examined and reported by E. R. Ayrton and published later, in 1930, by Senarath Paranavitana (Figure 2). The main inscription carved on a natural rock north of the stupa clearly describes a seaport in Godawaya. The inscription, dated back to the $1 \mathrm{st}$ or 2 nd century CE, Paranavitana ${ }^{6}$ describes the collection of customs duties from 'Godapavatha Patana'. The inscription consists of two lines. It says:

'Success! The customs duties of the port of Godapavatha, King Gamani Abaya granted to the vihara [temple].'

The names Godapavatha, Gotapabbata or Godawaya refer to a boulder (Gota - short and round/Pabbata - rock). The small stupa built on a rock to the south of the temple is clearly visible from the sea and may have been used as a landmark. Most probably the name Godapawatha could have been a name coined or used by the early seafarers. This evidence of an old port indicated in the inscription provided a clue to maritime archaeologists to search this area for a shipwreck or any other remains from this period.

Since 2008, the site has been measured and exploratory studies conducted; a site plan drawn and artefacts brought up and analysed. Most of the potshards have been identified as black and red ware (BRW), a particular type of clay ware unique to South Asia (Figures 3 and 4). These provide a clear idea of the likely origins of these artefacts. In particular, the pottery could be identified as cargo from this wreck and presented an opportunity to establish the age of the wreck, though not its origins. According to the comparative typological evaluation (with the aid of typologies of the early scientific excavations in Sri Lanka and India), the wreck has been tentatively dated to between the 2nd century BCE and 2nd century CE (ref. 7).

A few explorations, non-disturbance surveys and a series of short-term excavations have been completed after 2008 by different research institutes. Due to and following the war and a resultant lack of funding for underwater archaeology, the fieldwork was not carried out continuously. Investigations in 2010 by the MAU with an international team of maritime archaeologists provided much needed resources to survey the wreck site and a deeper understanding of the artefacts on the site. This collaborative fieldwork was funded by the CCF of Sri Lanka and the Cultural Heritage Agency of the Netherlands and UNESCO. During the same year,

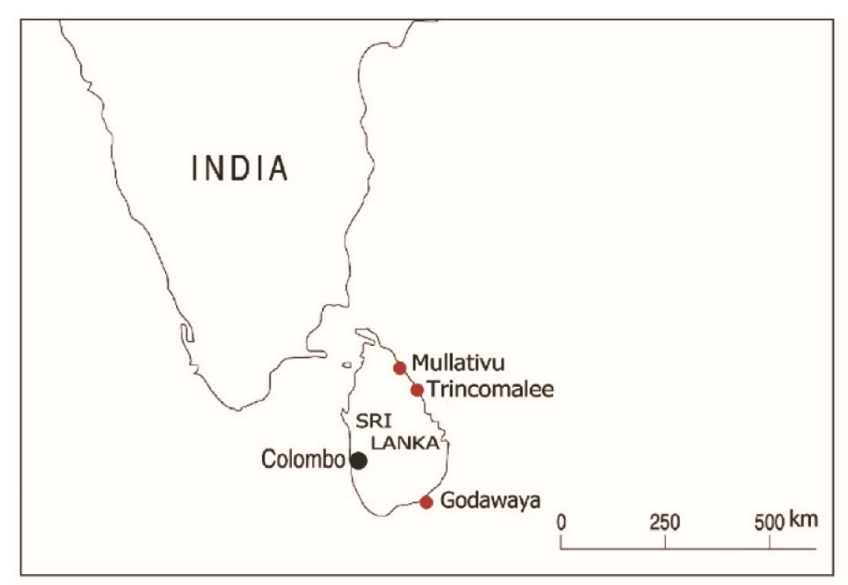

Figure 1. Map of Sri Lanka with the locations of Godawaya and Mullativu.

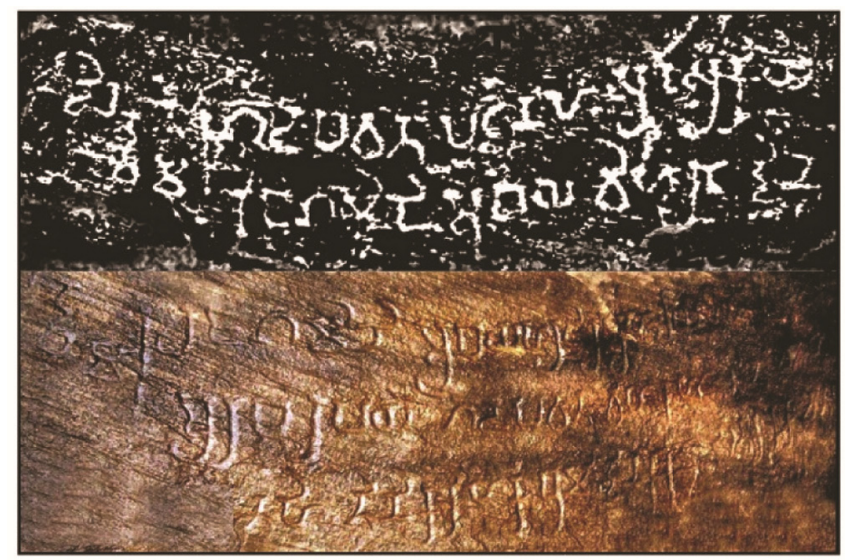

Figure 2. Godawaya inscription (Rasika Muthucumarana). 
another team of experts from the Institute of Nautical Archaeology (INA - Texas, USA) came to Godawaya to inspect the wreck and collect some samples for dating ${ }^{8}$.

From the end of 2011 to 2014 three field sessions resulted in further explorations and excavation at the Godawaya shipwreck by the Department of Archaeology along with collaboration with the INA and participation by team members from the MAU. This was the first systematic excavation done at the Godawaya shipwreck site. The south and east sides of the wreck were partly excavated, and it provided an opportunity to understand the formation of the wreck site and the density of the artefact layer beneath the sand. The INA excavation project was postponed and later terminated due to issues

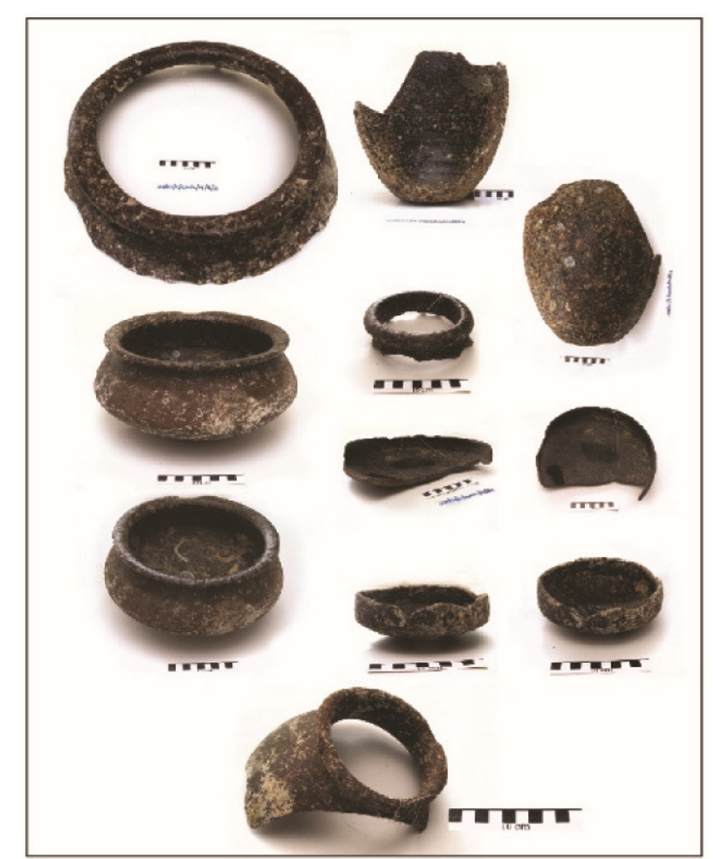

Figure 3. Artefacts/pottery raised in 2008 from Godawaya shipwreck site (Rasika Muthucumarana).

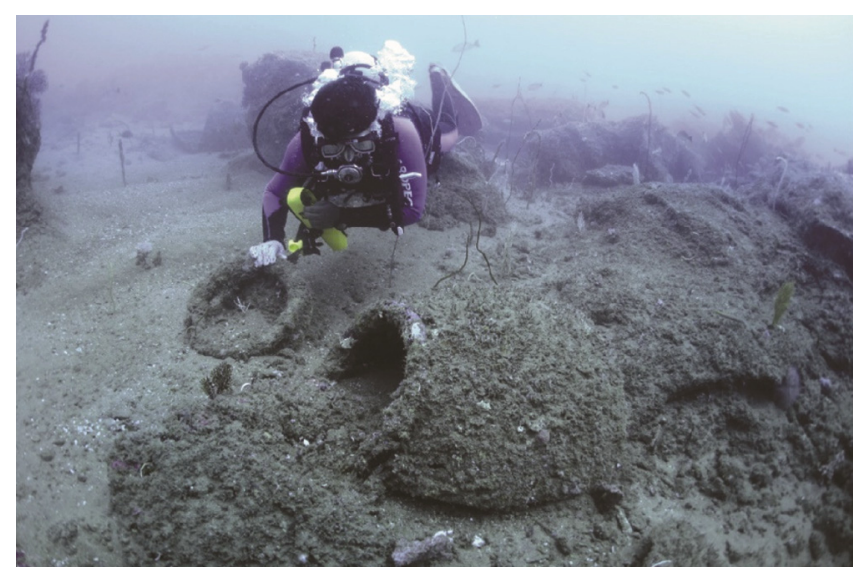

Figure 4. Large clay jar/storage jar on Godawaya shipwreck site (Rasika Muthucumarana). related to heritage management and ownership. However, after resolving these issues in November 2017, the Maritime Archaeology Unit and the Department of Archaeology managed to start field work at Godawaya.

The site was re-surveyed and prepared for further excavations and investigations. One small scale test excavation and a trench across the shipwreck were maintained. Investigations were carried out to find information of the ship's construction (Figure 5). Artefacts and raw materials, possibly ingots such as iron, copper and glass were found on the wreck.

Relative dating and $\mathrm{C}^{14}$ dating of the wood samples showed that the site was more than 1900-years-old, which suggest that it belonged to an era in which the temple inscription was carved or earlier. Two samples were taken from the wreck. One was sent to the CSIR-National Institute of Oceanography (NIO), Goa, India which was dated at the Physical Research Laboratory (PRL), Ahmedabad $^{9}$. The second sample was dated by the INA, Texas, USA ${ }^{10}$. Both were dated to between the 2 nd century $\mathrm{BCE}$ and 1 st century $\mathrm{CE}$ which is similar to the comparative dates given to the pottery found on the wreck. The surface observation indicated that a large part of the wreck and most of the artefacts are buried in sediment and the extent of the site could only be determined after a complete investigation. The main mound containing the wooden remains could be the best place to find more answers.

With the field work completed in 2017 and 2018, the whole site and some of the significant features (artefacts) of the site were recorded using 3D photogrammetry (Figure 6). A detailed site plan was also compiled using physical measurements. Yet, more artefacts and more detailed information are required to be included on the map. There are three mounds on the site, two large parts and a small one in-between. After investigations in 2017 the researchers had the opportunity to clearly identify these as the wooden hull. The wreck is in a northwest to

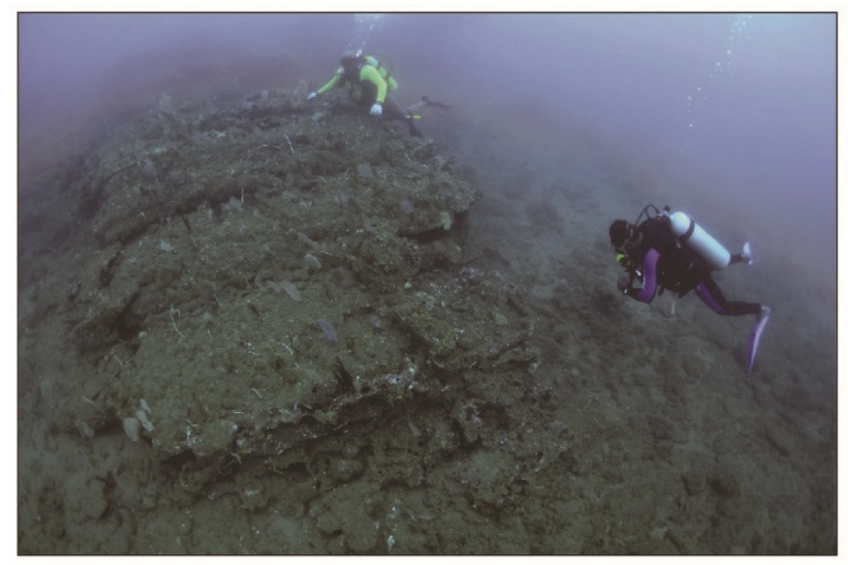

Figure 5. Wooden hull remains (Block 01/Mound 01) of the Godawaya wreck site (Rasika Muthucumarana). 
southeast orientation on a flat reef and sandy bottom. Yet, it is not certain whether the vessel is standing keel-down upright on the seabed or in a capsized orientation. The remains of the hull or the mounds that are visible on the site are heavily crusted with coral and concretion. At a few places, where the concretion is broken, the wooden remains are visible, and fragments of planks and frames can be seen. Considering the shape and position of the remains and artefact distribution, it is apparent that the vessel was intact when it reached the seabed. The wooden structure/hull has slowly disintegrated in weak places.

The majority of the artefacts found at the site are pottery and include various types of clay-ware, from large storage jars to small intake wares. Apart from jars and potsherds, artefacts uncovered from 2008 included stone querns, several cylindrical grinding stones, round and flat beads (Figure 7), fragments of several metal objects such as bowls and spearhead. One of the special artefacts from the site, a small blue glass disc shaped object, was found in 2013. It was finely made and could be a part of another object for this to be set within. Most of the pottery and the unused stone querns found with grinding stones can be identified as part of the cargo. Apart from those, a considerable quantity of raw materials was transported aboard the ship. There is little doubt that the hemispherical blue-glass ingots and copper were also part of the cargo (Figure 8). Remains of iron from the site also show some clues, that it could be transported as ingots. Further analysis of iron samples will likely solve in the future.

\section{SS Indus, the wreck with a reputation}

In 2009 the war that engulfed much of the country and spanned a period of over thirty years, ended. While terrorist operations were mainly concentrated over north

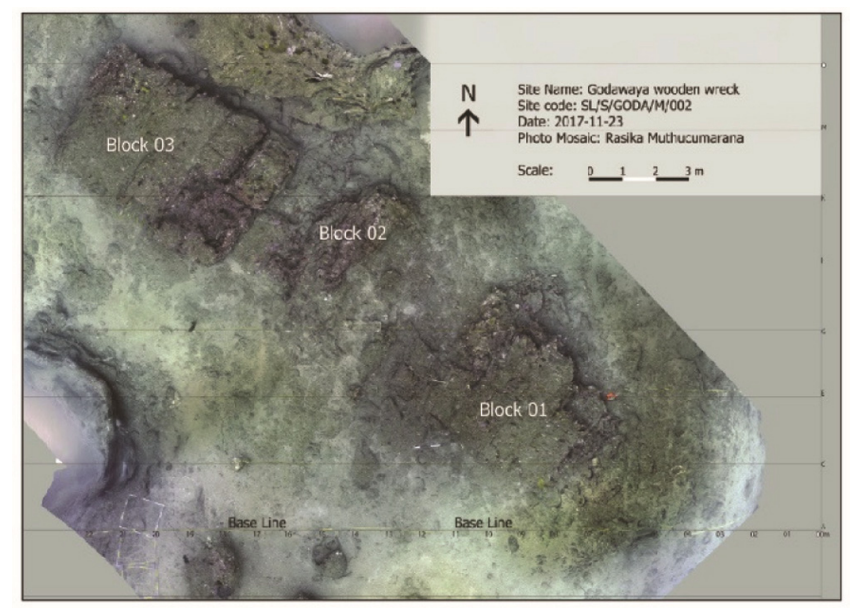

Figure 6. Three dimension photo model of Godawaya site. Three main mounds, Base line/ survey lines and artefacts around the site are shown. the model created with Agisoft photoscaner software (Project by Gamini Ranasinghe, Rasika Muthucumarana and Rukshan Priyandana). and east, it affected the entire country. After the war, the country's economy became more stable and tourism started to grow. With a return to more favourable financial conditions, the CCF management provided greater resources to the Maritime Archaeology Unit after 2010. The east, north and north-west coastlines were cleared by the security forces and opened to the public. From 2011 the MAU started working along the north-west coast and slowly reached the north and east coasts. Very little archaeological work has been done in these areas after 1985. Only the Sri Lanka Navy had the privilege of diving in these areas and that was only for military activity. Many 18th and 19th century shipwrecks are thought to lie in these areas, especially the east coast which is dense with steam powered iron wrecks and wrecks from WWII. Among these are some significant historical wrecks like HMS Hermes, HMAS Vampire and SS British Sergeant. There are also some mysterious shipwrecks known only through archives and rumours yet to be discovered. The SS Indus is one of the most highly ranked wrecks in this regard.

The name of the SS Indus is well known to Sri Lankan and Indian historians and archaeologists. It was widely believed that the ship was transporting a fine collection of sculptures from Bharhut, a well-known ancient Buddhist monastery in India from the 3rd century BCE. The ship was wrecked off Sri Lanka (Ceylon) in 1885 when returning from India via Colombo to London. Over the last century many researchers have attempted to locate the wreck and its cargo. At the time the SS Indus was wrecked, the renowned British scholar, Sir Alexander Cunningham was the head of Archaeological Survey of India (ASl). They believed his collection of masterpieces from Bharhut was on aboard, bound for the London Museum. The SS Indus ran aground in 1885 somewhere on the north-east coast of Sri Lanka while she was sailing from Calcutta (Kolkata) to London ${ }^{11}$.

The Bharhut Stupa is located in the present-day Satna District of Madhya Pradesh in India and was first identified by General Alexander Cunningham in 1873. On his second visit to Bharhut in February 1874 Cunningham collected and recorded scattered pieces of sculpture and

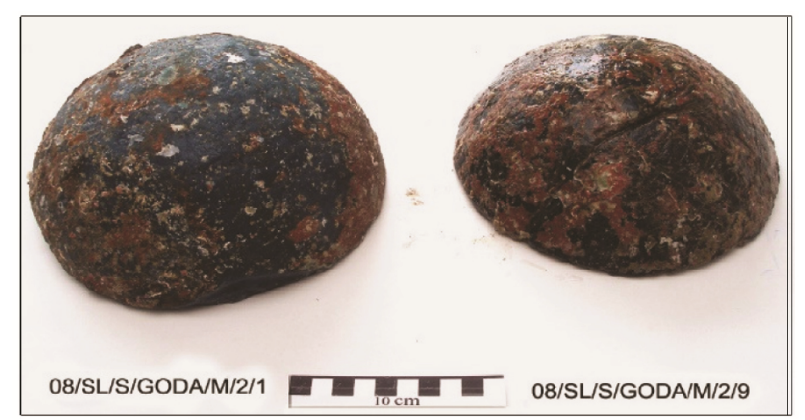

Figure 7. Hemispherical blue-glass ingots found in 2008. Photo by Rasika Muthucumarana. 


\section{SPECIAL SECTION: SHIPWRECKS}

tried to understand their layout and design. He returned there for a third time in November 1874 armed with legal rights and took several of the sculptures to Kolkata and founded a Bharhut Gallery in the National Museum at Kolkata. After a detailed study of Buddhist literature and sculptures from the site, he published a book in 1877 titled The Stupa of Bharhut, which remains a highly respected study of the Bharhut stupa ${ }^{12}$. Considering the work of Sir Alexander Cunningham, the loss of the SS Indus represents a monumental tragedy as it is believed to have been carrying the best pieces from this site.

One of the earliest reports on above incident is from 1901. James Burgess, the second Director General of the Archaeology Survey of India wrote: ... In November 1885, General Cunningham shipped a large and important collection to England, which was lost in the steamer 'Indus' off Ceylon ${ }^{13}$. Same was reported in a book published in 1964: ' ...the first two important collections of Gandharan art sent to Europe were lost. One, consisting of pieces from Jamal Garhi assembled by Sir Clive Bayley, was destroyed when the Crystal Palace in London burned down in 1866. In 1885 Cunningham sent to England a large collection that must have contained materials from Jamal Garji; it was lost at sea when the steamer Indus

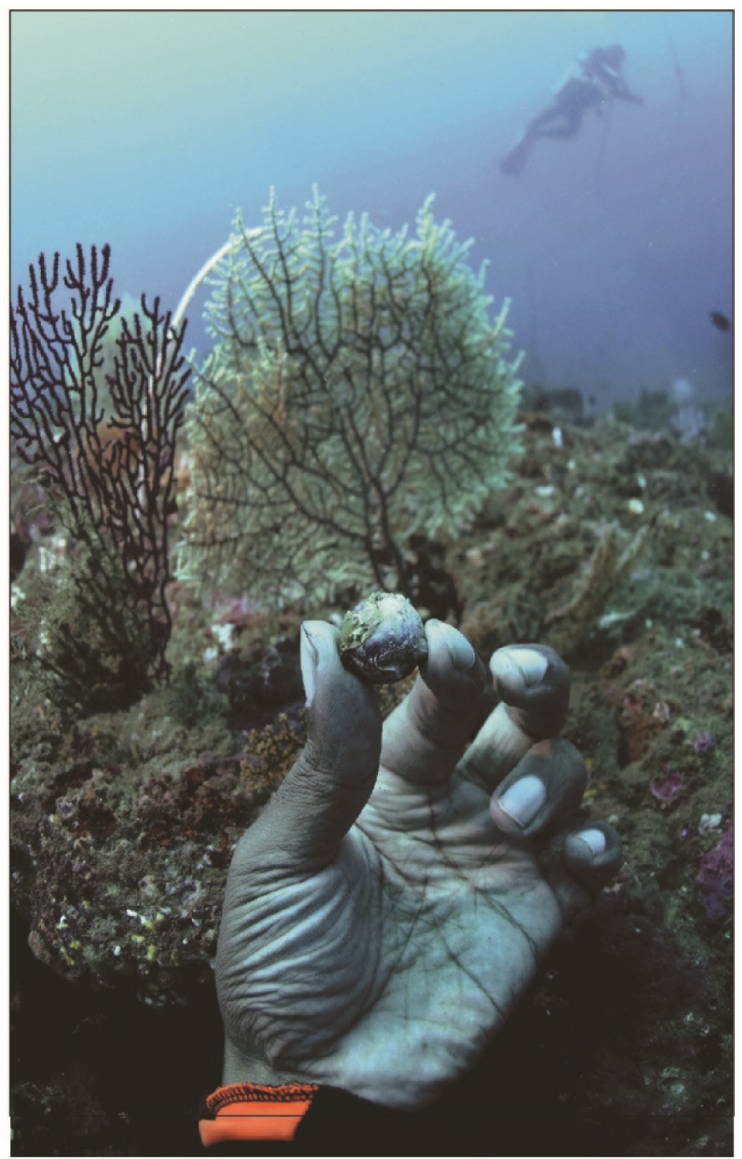

Figure 8. Orange colour bead (Carnelian?) found from the site (Rasika Muthucumarana). sank off the coast of Sri Lanka. It seems probable that some of the sculpture photographed by Caddy and Senart was on the Indus, thus, these early photographs are all the more valuable ${ }^{14}$ ', $\mathrm{Rao}^{15}$ states that the: 'P\&O Liner Indus which carried the second century BCE Buddhist Sculptures of Bharhut sank 50 miles north of Trincomalee in Ceylon in 1885. An attempt made to salvage them was not successful'. The Archaeological Commissioner of Sri Lanka, Charles Godakumbura, in his Annual Report for the year 1962-63 has made the following statement about the SS Indus: 'The possibility of doing more undersea archaeology in Ceylon in the near future takes our mind to the invaluable collection of works of art from the Stupa of Bharhut (2nd century BCE) lost of 1885 in the wreck of the $\mathrm{P} \& \mathrm{O}$ liner Indus that ship ran aground on a shoal known as Mullativu, 50 miles North of Trincomalee. It is known that some salvage operations were attempted at the time, with what result, we do not know. We shall therefore be thankful if anyone with information on this matter would pass on the same to Mr Arthur C. Clarke or to us $^{16}$.' The Late Sir Arthur C. Clarke also brought up the name Indus in his book Treasure of the Great Reef published in 1964. He presents a description of the supposed location of the site of the wreck as 'Fifty miles to the North of Trincomalee, on a shoal known as Mullaitivu, lays another important wreck and one which may contain the most valuable cargo lying beneath the waters around Ceylon. On 9 November 1885 the 3462 tonne $\mathrm{P} \& \mathrm{O}$ liner Indus was steaming south from Madras to Colombo when she ran aground at full speed due to a gross error in navigation. She was twenty miles off course, and her captain was lucky to get away with a twelve month suspension of his tickets .... At high tide, the Indus was wrecked off the shoal, and then had her second piece of bad luck. She came to rest immediately above one of her own anchors, and as she rose and fell in the waves, she quickly knocked a hole in her bottom and sank within a few hours. There was no loss of life, but none of the cargo could be saved. Aboard the Indus was the collection of the finest works of art from the stupa of Bharhut which had been specially selected by the director of the Indian Archaeology, General Cunningham. Today' these statues would be priceless - if they are still on Mullativu shoal. But we are not certain of this; we know that salvage operations were later carried out on the Indus with a view to recovering the indigo and other valuables aboard her. Would the divers also have bothered to bring up what they probably considered to be a few old statues? We rather doubt it, but until our researchers have settled this important point the Indus will remain on our list of possibilities, not certainties ${ }^{17}$.'

The story of the SS Indus was confined only to interested scholars as it was believed that the ship was wrecked in water so deep that scuba diving equipment could not be used in for exploration. It seems no one has made any serious effort to locate the wreck using the 
actual facts that related to the sinking. The war may also have been a contributing factor in preventing any physical survey of the area. After the MAU expanded their explorations to the north and east coasts from 2012, many wrecks have been recorded and documented. Fortunately, there is a well preserved collection of the 19th century newspapers in the Colombo National Archives. To locate and identify the history of these wrecks, researchers searched archival records, especially old newspapers. Further, information from local residents were also gleaned and the MAU carried out 'pre-surveys' along the targeted coastal areas during which there were opportunities to meet the local fishing communities and obtain useful and reliable information about shipwrecks. As a first step, archival research had been carried out to find evidence and confirm a possible location. Our research revealed that there had previously been great interest among scholars in finding this wreck. However, some misunderstanding about available information had thwarted their efforts; most notably, reports of its location being ' 50 miles north of Trincomalee' have proven to be misleading. The location ' 50 miles to north' is a deep-sea area, with depth between 300 and $600 \mathrm{~m}$ on Admiralty sea charts, and it is beyond the limits of scuba diving.

Narration by a passenger of the SS Indus - Times of Ceylon, Sunday the 15 September 1885 reads: 'We left Madras in the Indus at about a quarter to 2.00 p.m. on Saturday afternoon, the 8 September bound for London via Colombo. There were but seven first class passengers in all, and all went well until the morning of Sunday, the Indus coming to grief in reality but a few hours after we started. I had but just finished my chota hazeri on Sunday morning, and was just entering my cabin, when I felt the ship bump, and I was nearly thrown off my feet. Running on deck at once, as indeed did everybody, we found ourselves about four miles from land, which lay to starboard and grating against the bottom heavily. I believe, but I cannot say with certainty, that the captain was on the bridge with the officers of the watch at this time. I looked at my watch, and found it was just 6.20 a.m. But a few minutes previously, I had seen that we were in sight of land, and though I was rather surprised at this, I naturally did not give the matter much thought. The ships did not heel over but kept grating on the sandy bottom, and after a while the engines went full speed astern, part without any effect, though we moved from our position. The Captain then ordered the boats out with the lead, and sundry observations were taken from the ship and from the boats ... Captain Breeze still made frantic endeavours to get his ship out of the mass she was in, and the engineers were kept hard at it, but we seemed to get struck only the faster. Up to this time, though we had practically been fast for eight or ten hours, absolutely nothing had been done to lighten the ship by jettisoning the cargo, though the passengers suggested it to the
Captain more than once. The ship at this time, so far as we were informed, it must be remembered, had made no water. Towards the afternoon the anchor was let go, and attempt made to warp her off into deep water, which the boats had found by casting the led. This was the beginning of our worst misfortunes. I am unable to give a consecutive account of what took place during Sunday afternoon and night. Sleep we naturally get little of, and by morning we heard that the main hatch was full of water and the ship was fast. It appears that through some mismanagement we had gone ahead on our anchor and driven the fluke right into our bottom, and not content with this, we had gone on moving backwards and forwards, and had of course worked a great hole in the bottom of the vessel (Wreck of the P\&O SS Indus, The Times of Ceylon, 11 November 1885: 3). The ship was filling fast and we naturally desired to be out of danger. Our luggage was piled up on the main deck-to be washed in to the sea. As it eventually proved-but we were not allowed to take it ashore. We took a few wraps with us and rowed ashore with little or no difficulty. There we found a small fishing village called Mullativu where we went to the Rest house and made ourselves as comfortable as we could...' (Wreck of the P\&O SS Indus, The Times of Ceylon, 15 November 1885: 3).

The archival research confirmed that the ship was wrecked not too far from the land and the lifeboats reached the land within one hour, and the land (village) is known as Mullativu and they stayed at the rest house. Mullativu is the main town in Mullativu District, Northern Province of Sri Lanka. It had a rest house, which was demolished some time ago and a light house. According to the newspapers there have been attempts to excavate cargo from the Indus, but there is no evidence of any success. It is therefore highly likely that there has been no historical disturbance of the site, which likely remains untouched since the ship sank. There is no available evidence of disturbances soon after the shipwrecked, although there were severe waves during monsoon weather at that time. In later years before the availability of equipment to recover heavy items from a wreck or to stay underwater at such a depth for sufficient periods there was no apparent evidence of any attempts at recovery or salvage. There is a possibility that the strong waves may have resulted in sand covering the cargo which would add to the difficulty of retrieving it. Only in very recent times have new techniques and equipment become available to allow such excavation. These facts, together with Arthur C. Clarks' statement that he had not found the wreck or cargo, is evidence that if there are any remaining sculptures, they may remain intact beneath the sand. Information about the Indus appeared in a newspaper Times of Ceylon on the 12 and 13 of November 1885 and also from the account given by a passenger on the 15 th. The final piece of news of the ship's loss was printed on the 17 November 1885 . The news on the 12 November 
states: '... Information just brought by H.M.S. Ranger which has returned from the wreck with all passengers, native crew, and stewards, that the captain, chief and fourth officer and doctor are standing by the ship in boats. Ranger reports that the ship is settling down. The four compartments have been carried away, and the aftercompartment has started. The ship is full of water. No lives have been lost, and the mails are saved' (Wreck of the P\&O SS Indus, The Times of Ceylon, 12 November 1885: 3).

On 13 November, Times of Ceylon had reported on the cargo of the sunken ship. '... The Indus had a large consignment of some 200 chests-of indigo shipped at Madras and many thousands of chests of tea. The latter is of course done for, but the indigo may yet be recovered next year, for it suffers little deterioration in water ... the Indus being completely underwater and heavy seas braking over her. It is believed that the treasure on board-some $£ 40,000$ - has been saved, as the mails. According to the above list of items, there is no mention of the sculptures. It is probable that was a personal collection or not considered important at the time. Alternatively, its possible that it was a secret shipment to avoid unwanted publicity ...' (Wreck of the P\&O SS Indus, The Times of Ceylon, 13 November 1885: 3).

The last moments of the Indus according to The Times of Ceylon of Tuesday, 17 November 1885 reports: 'The Indus had not settled down to one side or the other, and her masts stood straight up with the sail caps on, clean and smart. Orders were left that as much as possible should be saved, and all that remained above water dismantled, but the bad weather coming on, compelled the wreck to be abandoned, and forced the brig to make the best of her way to Trincomalee, as already described' (Wreck of the P\&O SS Indus, The Times of Ceylon, 17 November 1885: 3).

More recently, archaeologists of the MAU have collected information from the field to find this missing wreck. There is a shipwreck marked on Admiralty sea charts $5.5 \mathrm{~km}$ southeast to the Mullativu lighthouse (Figure 9). In that area the depth is around 6-8 m. With calm sea conditions the sandy seabed is visible from above. For this depth scuba is not required and the team searched the whole area by snorkelling, but nothing was found. The 'pre-survey' was most useful in addition to meeting local fishing communities and building good relationships with them. Local fishermen confirmed there is no wreck or any foreign objects visible within the target area. The wreck marked on the Admiralty nautical chart appeared incorrect. The team did not find any divers in the Mullativu town as there was nothing much of interest to divers in that area. There are, however, some conch divers north of Mullativu, but non-locals visit this area once a year, set up camps and collect conches and sea cucumbers. They reside around Chalei and Pudumatalan area $14 \mathrm{~km}$ north of Mullativu and had no knowledge of possible wrecks. Finally, the team managed to find another diver who fishes south of Mullativu near Kokilai lagoon, who had some knowledge of an iron wreck opposite the Mullaitivu lighthouse. Following this lead, an iron wreck on a sandy bottom was located. The new location is $3.5 \mathrm{~km}$ north of the previously stated location (on the Admiralty charts) and $6 \mathrm{~km}$ north-east of the lighthouse. The half-buried iron wreck at $10 \mathrm{~m}$ depth was located but it appeared that most of the superstructure was salvaged some time ago. There were no remains or any identifying marks to indicate that this wreck was the SS Indus. There is no other record of a ship being lost in this area. The evidence on this site indicates that it is unlikely that the wreck had been previously excavated. The location and the distance match the reports from the 1885 newspapers. The area between the bow to mid-ship is fully covered with sand and has concealed the wreck. However, the amidships to the stern is half buried, and appears that around $2 \mathrm{~m}$ of the hull still under sand. Some cargo or other items remaining in the lower deck may well be preserved beneath the sand. To conduct an excavation, it is essential to establish the identity of the wreck, prior to expending valuable resources on an unknown entity.

During the years that followed, the MAU has attempted to identify the wreck by completing small scale excavations while recording and measuring the wreck site. In 2014 the site was measured, and a site plan drawn (Figure 12). The work was complicated due to the entanglement of fishing nets, creating difficulties and danger, and the nets were cleared before measurements commenced. The ships length and construction details are close to the specifications of the Indus, but there is no other evidence to confirm its identity. No work has been carried out during 2015. During the following year the team recommenced searching the wreck site by carrying out small scale excavations and clearing and cleaning the surface of

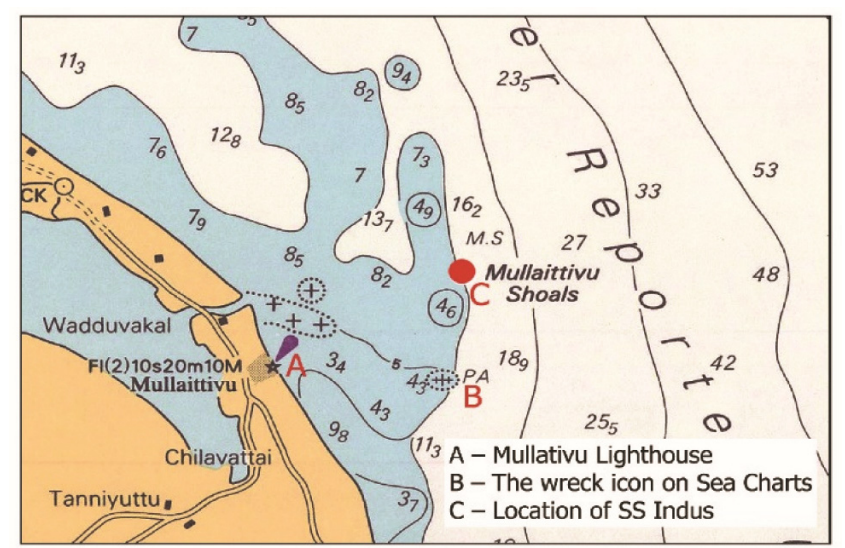

Figure 9. Locations of Mullativu Lighthouse, SS Indus wreck and wreck icon already shown on admiralty charts. Depths are shown in meters. 


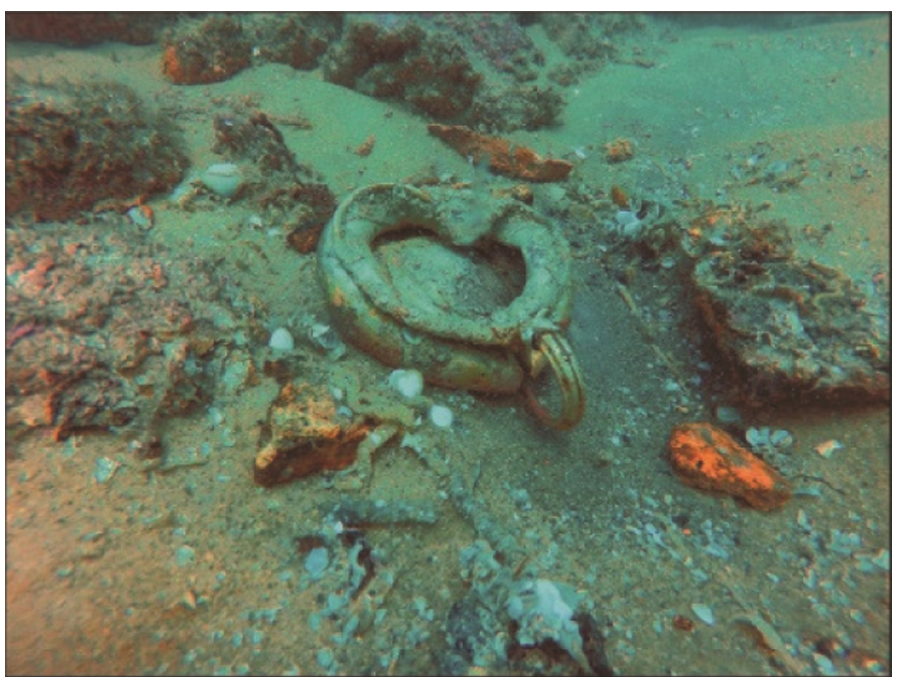

Figure 10. Alloy jar found from SS Indus (Rukshan Priyandana).

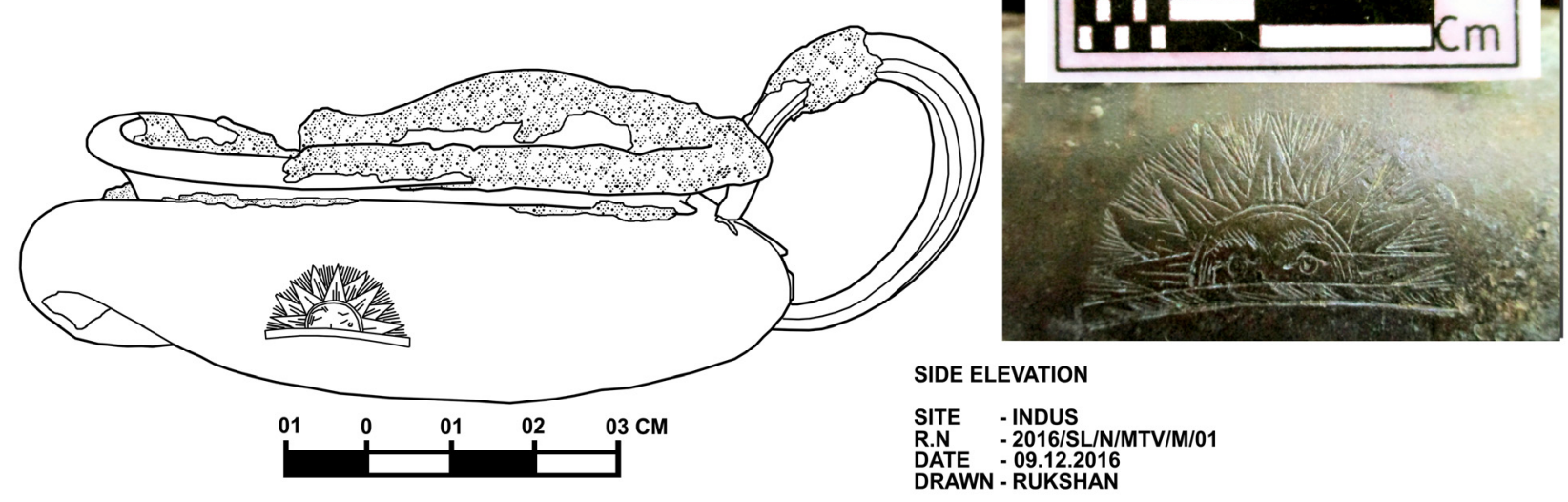

Figure 11. Photograph and drawing of the alloy jar with $\mathrm{P} \& \mathrm{O}$ Company logo (Rukshan Priyandana).
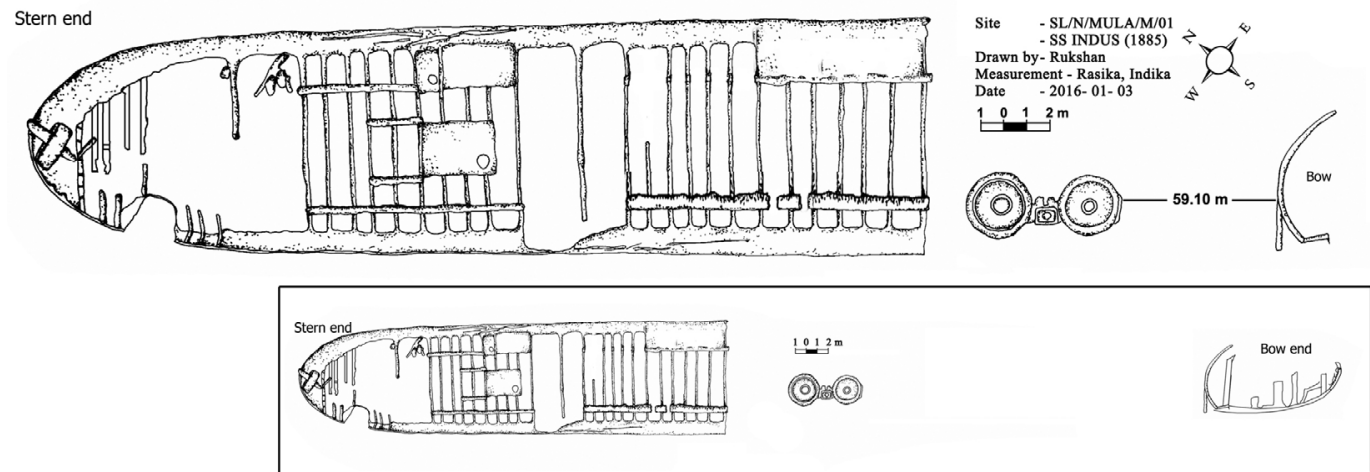

Figure 12. Site plan of the SS Indus (Rukshan Priyandana).

the deck floors. During these explorations some potsherds, metal objects and a tiled floor/deck floor area were found. Part of the deck was covered with terracotta tiles. This area was documented, and some pieces were brought up. Among the metal object there was a small jar with a symbol of the rising sun which is the symbol of the P\&O Company (Figures 10 and 11). This was one of the first positive indications that this was indeed the wreck 
of the SS Indus. With this lead, the field work and excavation work was carried out during 2017 with the intention of finding out the thickness of the sand cover inside the ship between amid-ship and stern. A $2 \times 2$ sq. $\mathrm{m}$ on the port side was selected for excavation. After recording the selected area, excavation was carried our using a water dredger. The excavation continued for nearly two weeks, but the team was unable to reach the bottom of the ship. There were lot of debris, seashells and concretions, which needed to be removed by hand as they created obstructions inside the suction hose, which needed constant clearing by divers which required them to frequently stop work. Another problem was the high rate of refilling and the team returned each day to find that the excavation trench was half filled during the night.

At the end of the field sessions, the excavation cleared more than $2 \mathrm{~m}$ to the bottom. Remains of the deck pillars, frames and the inside wall of the iron hull were recorded. While some unidentified, concreted iron objects and potsherds were found, there is no evidence of any stone objects or ancient artefacts. To continue the excavation for the future, a more powerful water dredge with suction is required. Greater manpower and extended field work is also required to remove the thick sand layer with debris. The identity of this shipwreck still remains buried and the Bharhut artefacts continue to be a mystery under the Mullativu sands.

1. Muthucumarana, R., The Ancient wreck at Godowaya. In Maritime Heritage of Lanka: Ancient Ports and Harbours (ed. Fernando, S.), Central Cultural Fund/National Trust, Colombo, Sri Lanka, 2013, pp. 132-139.

2. Clarke, A. C., Ceylon and the underwater archaeologist. In Expedition, 1964, 6(3) (Spring), pp. 19-31.

3. Parthesius, R., Miller, K., Devendra, S. and Green, J. (eds), Avondster Project Report 2001-2002, Amsterdam Historical Museum, The Netherlands, 2003, pp. 51-60.

4. Devendra, S. and Muthucumarana, R., Maritime Archaeology and Sri Lanka: globalization, immigration, and transformation in the underwater archaeological record. J. Soc. Hist. Archaeol., 2013, 47(1), 50-65.
5. Muthucumarana, M., Godawaya: an ancient port city (2nd century $\mathrm{CE})$ and the recent discovery of the unknown wooden wreck. Newsl. Australasian Inst. Maritime Archaeol., 2009, 28(3), 21-26.

6. Paranavithana, S., Inscriptions of Ceylon, Archaeological Survey of Ceylon, Colombo, 1983, vol. II(I), pp. 101-107.

7. Muthucumarana, R. et al., An early historic assemblage offshore of Godawaya, Sri Lanka: evidence for early regional seafaring in South Asia. J. Maritime Archaeol., 2014, 9(1), 41-58.

8. Carlson, D. N. and Trethewey, K., Shipwreck in Sri Lanka: an ancient cargo ship in the Indian Ocean. INA Qly, 2013, 40(1), 8-14.

9. Chandraratne, W. M. et al., SEM-EDS analysis of copper, glass and iron recovered from the 1 st century AD shipwreck site off Godawaya, Southern Sri Lanka. Curr. Sci., 2012, 103(5), 482-485.

10. Carlson, D. N., Köyağasioğlu, O. and Wills, S., The Ancient Shipwreck Excavation at Sri Lanka: finds from the oldest shipwreck in the Indian Ocean. INA Oly, 2015, 42(2), 12-19.

11. Nandadasa, S. M., The discovery SS Indus (1885) with Cargo of the 3rd century BC Bharhut sculptures in Sri Lankan waters. In Proceedings of the 2nd Asia-Pacific Regional Conference on Underwater Cultural Heritage, Hawaii, 2014, vol. I, pp. 923-936.

12. Cunningham, A., The Stupa of Bharhut: A Buddhist Monument Ornamented with Numerous Sculptures Illustrative of Buddhist Legend and History in the Third Century BCE, Secretary of State for India in Council, London, 1879.

13. Burgess, J., Buddhist Art in India; Translated from the 'Handbook' of Prof Albert Grunwedel, Bernard Quaritch, London, 1901, p. 83 .

14. Behrendt, K. A., The Buddhist Architecture of Gandhara, Section 2 - South Asia (eds Alam, M., Bronkhorst, J., Jacobsen, K. A.), Handbook of Oriental Studies, USA, 1964, p. 113.

15. Rao, S. R., Progress and Prospects of Marine Archaeology in India, National Institute of Oceanography, Goa, 1987.

16. Godakumbura, C. E., Administration Report of the Archaeological Commissioner for the Financial year 1962-63, Government Publication Bureau, Colombo, 1964.

17. Clarke, A. C., The Treasure of the Great Reef, Ballantine Books Inc, New York, 1st revised print, 1974, pp. 176-177.

ACKNOWLEDGEMENTS. I thank Prof. P. B. Mandawala, Director General of Archaeology for granting permission to its rightful owners to undertake the Godawaya research work, Dr Amal Karumaratne for editing the paper, S. M. Nandadasa (former Officer in charge of MAU), Rukshan Priyanadanaand, Palitha Weerasinghe, Amalka Wiesuriya and all team members of the MAU.

doi: $10.18520 / \mathrm{cs} / \mathrm{v} 117 / \mathrm{i} 10 / 1664-1672$ 